\title{
ЕКСПЕРИМЕНТАЛЬНО-ТЕОРЕТИЧНИЙ РОЗДІЛ
}

\author{
УДК [616. $311+616.315]: 615.24$
}

\author{
Г.А. Єрошенко, Ю.В.Тимошенко
}

\section{ТРАНСФОРМАЦІЯ ІНТЕНСИВНОСТІ МАРКІРУВАННЯ КОМПОНЕНТІВ СЛИЗОВОЇ ОБОЛОНКИ ТВЕРДОГО ПІДНЕБІННЯ ЗА ДОПОМОГОЮ ЛЕКТИНУ КОРИ ЗОЛОТОГО ДОЩУ ЗВИЧАЙНОГО (LAВА) В УМОВАХ ДIÏ 1\% ЕФІРУ МЕТАКРИЛОВОЇ КИСЛОТИ}

Українська медична стоматологічна академія, Полтава, Україна

Збільшення середньої тривалості життя людини, виникнення патології твердих тканин зубів і тканин пародонта призводять до прогресуючої втрати зубів. Унаслідок цього виникає потреба в зубних протезах. Знімні акрилові протези найдоступніші при частковій і повній адентії. Але багато пацієнтів (до $30 \%$ ) із протезами зовсім не можуть ними користуватися або застосовують їх тільки під час їди і мовлення. Усі причини можна об'єднати в такі групи: 1 -механічні фактори, надлишковий тиск на тканини протезного ложа; 2 - токсико-хімічні (псевдоалергічні); 3 - алергічні (загальні й місцеві), вплив компонентів пластмас; 4 - соматичні хвороби (хронічні інфекції, обмінні, психічні порушення та ін.); 5 - вплив продуктів мікрофлори, яка колонізує базиси протезів і може викликати явища непереносимості, й т.д. [1; 2]. Деякі автори виявляють "протезні стоматити" у 25\%-69\% обстежених хворих і вважають причиною їх виникнення наявність надлишку мономера в базисах протезів [3-5].

У практиці ортопедичної стоматології в ролі мономера для виготовлення знімних конструкцій зубних протезів використовують метиловий ефір метакрилової кислоти, який при співполімеризації з порошковою масою повністю не полімеризується.

Залишковий мономер спричиняє збудження рецепторів слизової оболонки порожнини рота, слинні залози рефлекторно на першому етапі підвищують свою активність, збільшуючи виділення слини, що забезпечує нейтралізацію i змивання мономера зі слизової оболонки порожнини рота. Але потім настає виснаження слинних залоз. Гіперфункція змінюється гіпофункцією й атрофічними процесами в слинних залозах.

Мета роботи - визначити трансформацію інтенсивності маркірування компонентів слизової оболонки твердого піднебіння за допомогою фукозос- пецифрічного лектину кори золотого дощу звичайного (LABA) при дії 1\% ефріру метакрилової кислоти за умов експериментальної гіпосалівації.

\section{Матеріал і методи дослідження}

Дослідження було проведено на 20 білих безпородних щурах-самцях. П'ять тварин склали контрольну групу і 15 - експериментальну. Гіпосалівацію було змодельовано шляхом обробки слизової оболонки рота щурів $1 \%$ розчином метилового ефріру метакрилової кислоти протягом 30 днів [6]. Тварин виводили з експерименту на 14 і 30 добу шляхом передозування тіопенталового наркозу.

Лектини - білки і глікопротеїни, що мають здатність високоспецифічно зв'язувати залишки вуглеводів на поверхні клітин. Лектини зазвичай беруть участь у клітинному розпізнаванні, наприклад, деякі патогенні мікроорганізми використовують лектини для прикріплення до клітин ураженого організму.

Метод лектинового зондування за своєю чутливістю і селективністю виявлення вказаних молекулярних структур значно перевершує традиційні методи гістохімічної верифікації вуглеводів [7;8].

3 метою визначення вуглеводних компонентів структурних елементів слизової оболонки залозистої зони твердого піднебіння ми використали метод лектиногістохімії [9].

Інтенсивність маркірування інтактної групи за допомогою фукозоспецифічного лектину кори золотого дощу звичайного (LABA) установлено сильний ступінь кон'югації з рецепторами рогових лусочок і базальної мембрани. Слабкою була реакція клітин зернистого, шипуватого і базального шарів (табл. 1). Експресія рецепторів фрібробластів власної пластинки була помірною, колагенових волокон - слабкою. Еластичні мембрани артеріол проявляли негативну реакцію. 
Реакція рецепторів на ендотеліоцитах судин і базальній мембрані була слабкою. 3 боку макрофрагів, лімфоцитів і мастоцитів - сильна реакція (рис.1).

Спорідненість структурних компонентів підне-

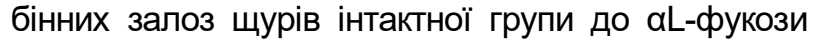
була слабкою до цитоплазми і базальної плазмолеми епітеліоцитів кінцевих відділів (табл. 1). Інтенсивність маркірування поверхні й цитоплазми міоепітеліоцитів була помірною (рис. 2). Експресія рецепторів до aL-фукози була сильною з боку міоепітеліоцитів вивідних проток. Спорідненість цитоплазми, базальної мембрани і базальної плазмолеми протокових епітеліоцитів була слабкою (табл. 1). До 14-ї доби спостереження інтенсив-

ність зв'язування рецепторів рогових лусочок до лектину знизилася до помірної. Експресія рецепторів на клітинах зернистого, шипуватого, базального шарів і базальної мембрани залишилася сталою на рівні слабкої (рис. 3). Дослідження специфрічності зв'язування компонентів власної пластинки визначило сталу експресію рецепторів до aLфукози з боку фібробластів та посилення до помірної - колагенових волокон. Реакція з боку компонентів судинної стінки залишалася слабкою і негативною - з боку еластичної мембрани артеріол (див. табл. 1). Спорідненість рецепторів до aLфукози макрофрагів зменшилася до слабкої, лімфоцитів - до помірної, мастоцитів посилилася із сильної до дуже сильної (рис. 4).

Таблиця 1

Лектинохімічна характеристика слизової оболонки залозистої зони твердого піднебіння щурів при зондуванні лектином кори золотого дощу звичайного (LABA)

\begin{tabular}{|c|c|c|c|c|c|}
\hline \multicolumn{3}{|c|}{ Структурні компоненти } & Інтактна група & 14 доба & 30 доба \\
\hline \multirow{5}{*}{ Епітелій } & \multicolumn{2}{|c|}{ роговий шар } & 3 & 2 & 2 \\
\hline & \multicolumn{2}{|c|}{ зернистий шар } & 1 & 1 & 2 \\
\hline & \multicolumn{2}{|c|}{ шипуватий шар } & 1 & 1 & 2 \\
\hline & \multicolumn{2}{|c|}{ базальний шар } & 1 & 1 & 1 \\
\hline & \multicolumn{2}{|c|}{ базальна мембрана } & 3 & 1 & 1 \\
\hline \multirow{8}{*}{$\begin{array}{c}\text { Власна плас- } \\
\text { тинка }\end{array}$} & \multicolumn{2}{|c|}{ фрібробласти } & 2 & 2 & 3 \\
\hline & \multicolumn{2}{|c|}{ колагенові волокна } & 1 & 2 & 3 \\
\hline & \multirow{3}{*}{ судини } & ендотеліоцити & 1 & 1 & 2 \\
\hline & & базальна мембрана & 1 & 1 & 2 \\
\hline & & еластична мембрана & 0 & 0 & 0 \\
\hline & \multirow{3}{*}{$\begin{array}{c}\text { мігрантні } \\
\text { клітини }\end{array}$} & мастоцит & 3 & 4 & 4 \\
\hline & & лімфоциити & 3 & 2 & 2 \\
\hline & & макрофраги & 3 & 1 & 1 \\
\hline \multirow{8}{*}{ Залози } & \multirow{4}{*}{ кінцеві відділи } & базальна мембрана & 1 & 2 & 2 \\
\hline & & плазмолема & 1 & 1 & 2 \\
\hline & & цитоплазма & 1 & 1 & 1 \\
\hline & & міоепітеліоцити & 2 & 3 & 1 \\
\hline & \multirow{4}{*}{ вивідні протоки } & базальна мембрана & 1 & 2 & 2 \\
\hline & & плазмолема & 1 & 1 & 2 \\
\hline & & цитоплазма & 1 & 1 & 1 \\
\hline & & міоепітеліоцити & 3 & 3 & 1 \\
\hline
\end{tabular}

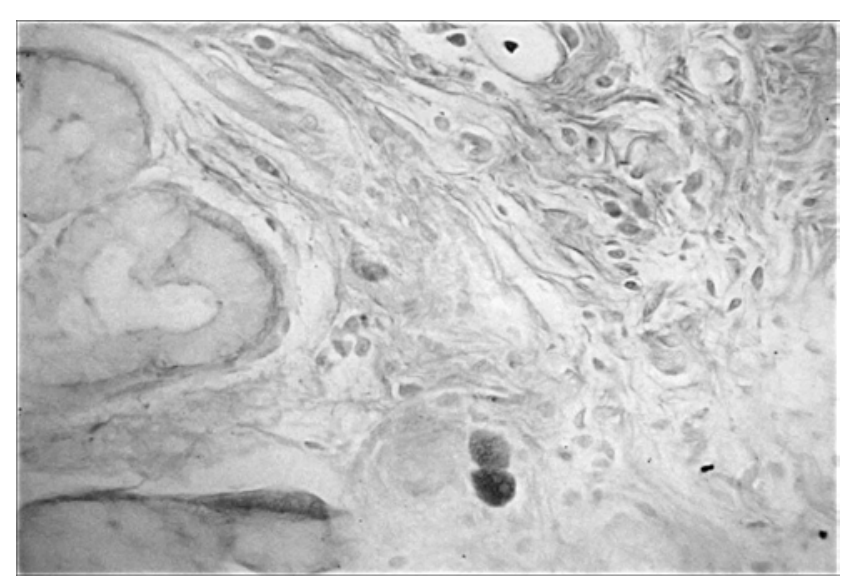

Puc. 1. Сильна експресія фукозоспецифрічного лектину кори золотого дощу звичайного на мастоцитах, лімфоцитах і макрофрагах та помірна на колагенових волокнах у власній пластиниі залозистої зони твердого піднебіння щура інтактної групи.

LABA- маркірування. Зб.: Об. х 100, Ок. х 10

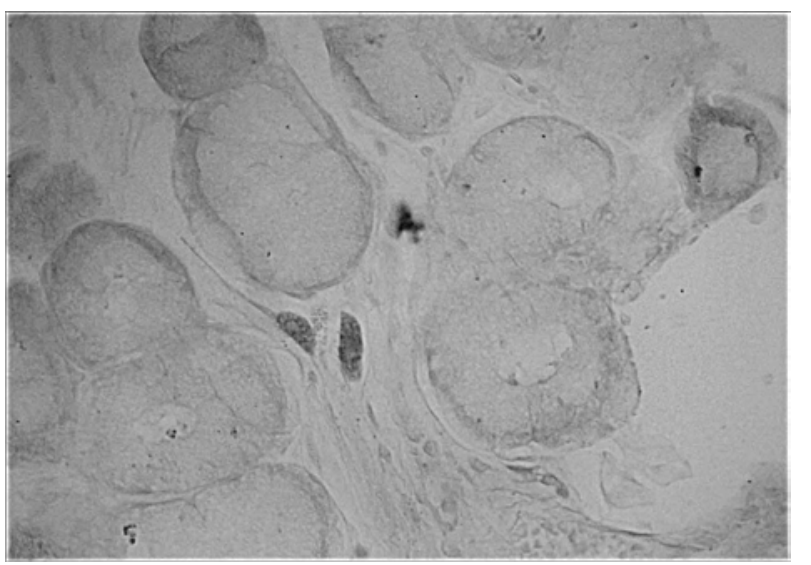

Рис. 2. Помірна експресія фрукозоспецифрічного лектину кори золотого дощу звичайного на міоепітеліоцитах кінцевих відділів слинних залоз залозистої зони твердого піднебіння щура інтактної групи.

LABA-маркірування. Зб.: Об. х 100, Ок. х 10 


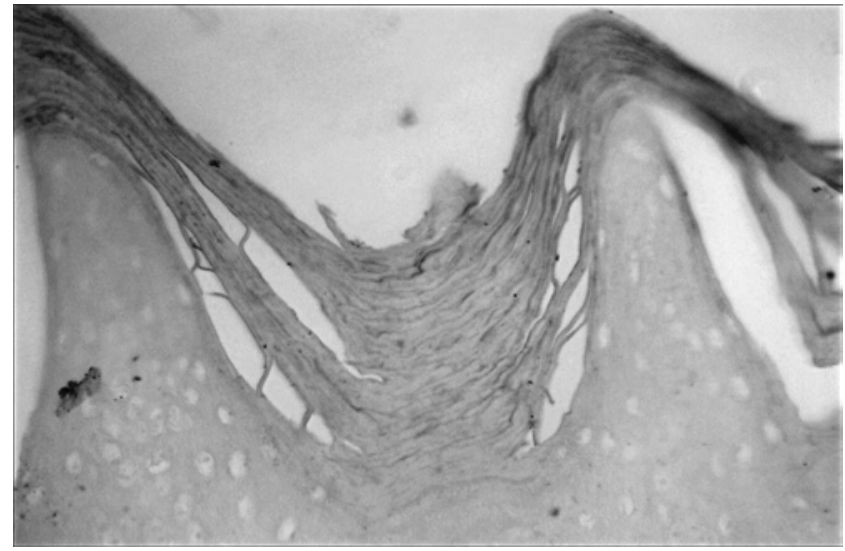

Puc. 3. Зниження інтесивності експресії

фукозоспецифрічного лектину кори золотого дощу звичайного на рогових лусочках епітеліальної пластинки слизової оболонки залозистої зони твердого піднебіння щура на 14 добу спостереження. LABA-маркірування. Зб.:Об. х 100, Ок. х 10

На 14 добу експерименту визначено посилення експресії рецепторів до LABA на базальній мембрані кінцевих відділів до помірної, міоепітеліоцити проявляли сильну реакцію.

На 30 добу спостереження в епітеліальній пластинці залозистої зони слизової оболонки твердого піднебіння щурів реакція з боку рогових лусочок залишилася сталою помірною, базального - сталою слабкою. Посилення зв'язування рецепторів до лектину визначено в шипуватому і зернистому шарах до помірного в порівнянні 3 інтактною групою тварин і на 14 добу спостереження (рис. 5).

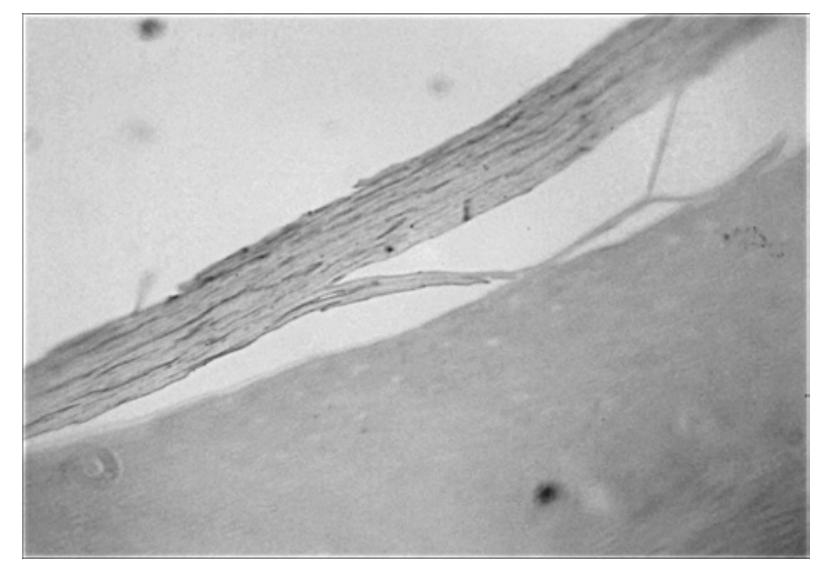

Рис. 5. Помірна експресія фрукозоспецифрічного лектину кори золотого дощу звичайного на рогових лусочках, кератиноцитах зернистого і шипуватого шарів епітеліальної пластинки слизової оболонки

залозистої зони твердого піднебіння щура на 30 добу спостереження.

LABA-маркірування. Зб.: Об. х 100, Ок. х 10

У власній пластинці посилилася до сильної експресія рецепторів в цитоплазмі фібробластів і колагенових волокнах. До помірної посилилася реакція рецепторів на ендотеліоцитах і базальній мембрані судин гемомікроциркуляторного русла. Реакція з боку мастоцитів була дуже сильною, лімфоцитів - помірною, макрофрагів слабкою і від попереднього терміну спостереження не відрізнялася (рис. 6).

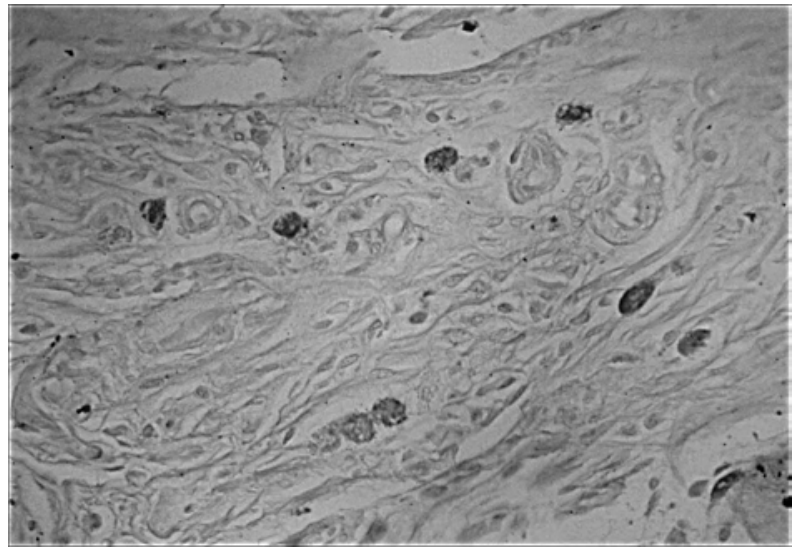

Рис. 4. Посилення експресії фуккозоспецифрічного лектину кори золотого дощу звичайного на мастоцитах і зменшення до помірної на лімфоцитах у власній пластинці залозистої зони твердого піднебіння щура на 14 добу спостереження.

LABA- маркірування. Зб.: Об. х 100, Ок. х 10

3 боку кінцевих відділів піднебінних залоз на 30 добу експерименту встановлено збереження помірної інтенсивності експонування вуглеводних детермінант до лектину кори золотого дощу звичайного на базальній мембрані (слабка в інтактній групі та помірна на 14 добу спостереження) та слабкої в цитоплазмі епітеліоцитів (слабка в інтактній групі й на 14 добу експерименту).

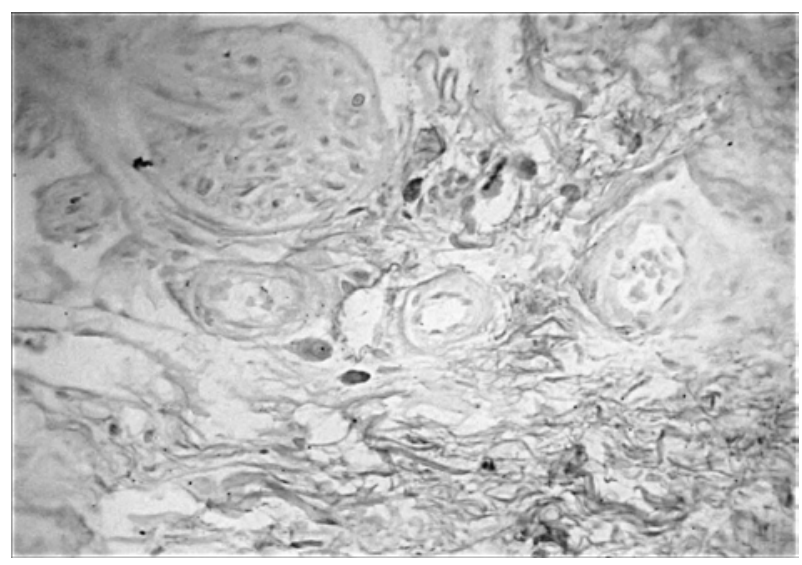

Puc. 6. Дуже сильна експресія фрукозоспецифічного лектину кори золотого дощу звичайного

на мастоцитах і сильна - на колагенових волокнах і фрібробластах у власній пластинці залозистої зони твердого піднебіння щура на 30 добу спостереження.

LABA- маркірування. Зб.: Об. х 100, Ок. х 10

Посилилася реакція зі слабкої до помірної на базальній плазмолемі епітеліоцитів кінцевих відділів. Із сильної до слабкої знизилась експресія рецепторів до лектину LABA на міоепітеліоцитах кінцевих відділів (див. табл. 1). Визначення специфічності зв'язування фукозоспецифічного лектину кори золотого дощу звичайного 3 рецепторами структурних компонентів вивідних проток піднебінних залоз на 30 добу спостереження визначило помірну реакцію базальної мембрани і плазмолеми. Цитоплазма міоепітеліоцитів і базальна цитоплазма проявляли слабке маркірування (див. табл. 1). 


\section{Висновок}

Інтенсивне маркірування інтактної групи за допомогою фукозоспецифічного лектину кори золотого дощу звичайного (LABA) установило сильний ступінь кон'югації з рецепторами рогових лусочок і базальної мембрани. Інтенсивність маркірування поверхні й цитоплазми міоепітеліоцитів була помірною. 3 боку макрофрагів, лімфоцитів і мастоцитів - сильна реакція. Експресія рецепторів до $\alpha \mathrm{L}-$ фукози була сильною з боку міоепітеліоцитів вивідних проток.

Ha 14 добу спостереження інтенсивність зв'язування рецепторів рогових лусочок до лектину зменшилася до помірної, що морфологічно проявлялося гіперкератозом на цей термін спостереження. Дослідження специфічності зв'язування компонентів власної пластинки визначило

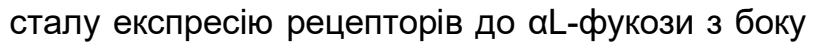
фібробластів та посилення до помірної - колагенових волокон. У власній пластинці визначено морфологічні ознаки гіпергідратації. Експресія рецепторів на клітинах зернистого, шипуватого, базального шарів і базальної мембрани залишилася сталою на рівні слабкої.

На 30 добу спостереження в епітеліальній пластинці залозистої зони слизової оболонки твердого піднебіння щурів реакція з боку рогових лусочок залишилася сталою помірною, базального - сталою слабкою. Посилення зв'язування рецепторів визначено в шипуватому і зернистому шарах до помірного. Морфологічно товщина епітеліальної пластинки достовірно зменшилася порівняно з показником у інтактній групі, що зумовлено порушенням процесів диференціації за типом паракератозу.

Повного відновлення морфо-функціонального стану пухкої сполучної тканини не встановлено.

Дані про особливості морфологічних змін залозистої зони слизової оболонки твердого піднебіння та піднебінних залоз при гіпосалівації можуть бути використані в ролі наукового і методологічного підґрунтя для подальшої розробки методів діагностики та комплексного лікування стоматологічних хворих на терапевтичному й ортопедичному прийомі.

\section{Література}

1. Biocompatibility of polymethylmethacrylate resins used in dentistry / R. Gautam, R. D. Singh, V. P. Sharma [et al.] // Journal of Biomedical Materials Research Part B: Applied Biomaterials. - 2012. Vol. 100B, is. 5. - P. 1444-1450.

2. Сафраров А.М. Состояние слизистой оболочки протезного ложа при съемном протезировании / А.М. Сафаров // Вісник стоматології. - 2010.- № 2. - C.121-123.

3. Кузь В.С. Характеристика сучасних базисних стоматологічних матеріалів та їх вплив на тканини порожнини рота/ В.С. Кузь, В.М. Дворник, Г.М. Кузь //Актуальні проблеми сучасної медицини:Вісник УМСА.- 2014.- Т.14, вип. 2(46).- С.179184.

4. Косенко К. Н. Состояние стоматологической помощи в Украине / К. Н. Косенко, О. Э. Рейзвих // Экономика и менеджмент в стоматологии. 2012. - № 2 (37). - С. 57-61.

5. Нідзельський М. Я. Структурні зміни в зубних протезах, виготовлених з акрилових пластмас, у різні строки користування ними та їх вплив на тканини порожнини рота / М. Я. Нідзельський, Л. Р. Криничко // Современная стоматология. 2011.- № 5. - С. 88-91.

6. Бабій Р.І. Корекція фрункціональної активності слинних залоз при зубному протезуванні хворих з гіпосалівацією: дис. на здобуття наук. ступеня канд. мед. наук:спец. 14.01.22 «Стоматологія»/ Р. І. Бабій. - Одеса,2008. - 143 с.

7. Білаш С.М. Лектинохімічна характеристика вуглеводних детермінант шлунку при введенні кріоконсервованої плаценти на тлі гострого експеримнтального запалення / Білаш С.М., Єрошенко Г.А., Покотило П.Б. // Світ медицини та біології. 2013, № 1 (36). - С.94 - 99.

8. Антонюк Р. В. Лектиногістохімічне дослідження товстої кишки людини в нормі та при неопластичних процесах з використанням лектинів, специфічних до Т-антигену та N-ацетиллактозаміну /P. В.Антонюк, О. Д. Луцик // Світ медицини та біолоriï. - 2015, № 4(53). - С. 15-18.

9. Єрошенко Г. А. Methacrylate-induced changes in metric parameters of rat palatine glands / Г.A. Єpoшенко, Ю.В. Сенчакович, А.І. Єрошенко // European International Journal of Science and Technology. - 2015. - Vol.4, No. 3.- P.132-135.

Стаття надійшла 18.03.2019 p.

\section{Резюме}

Інтенсивне маркірування за допомогою фукозоспецифічного лектину кори золотого дощу звичайного (LABA) слизової оболонки твердого піднебіння щурів за умов дії 1 \% ефіру метакрилової кислоти встановило, що на 14 добу спостереження інтенсивність зв'язування рецепторів рогових лусочок зменшилася до помірної, що морфологічно проявлялося гіперкератозом на цей термін спостереження. Дослідження специфічності зв'язування компонентів власної пластинки визначило сталу експресію

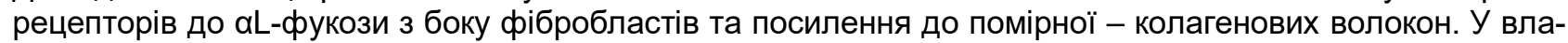
сній пластинці визначено морфологічні ознаки гіпергідратації. Експресія рецепторів на клітинах зернистого, шипуватого, базального шарів і базальної мембрани залишилася сталою на рівні слабкої.

На 30 добу спостереження в епітеліальній пластинці залозистої зони слизової оболонки твердого піднебіння щурів реакція з боку рогових лусочок залишилася сталою помірною, базального - сталою слабкою. Посилення зв'язування рецепторів визначено в шипуватому і зернистому шарах до помірного. Морфологічно товщина епітеліальної пластинки достовірно зменшилася порівняно з показником у інтактній групі, що зумовлено порушенням процесів диференціації за типом паракератозу.

Ключові слова: слизова оболонка, лектини, гіпосалівація, експресія. 


\section{Резюме}

Интенсивное маркирование с помощью фукозоспецифичного лектина коры золотого дождя обычного (LABA) слизистой оболочки твердого неба крыс в условиях действия 1\% эфира метакриловой кислоты установило, что на 14 сутки наблюдения интенсивность связывания рецепторов роговых чешуек снизилась до умеренной, морфологически проявлялось гиперкератозом на данный срок наблюдения. Исследование специфичности связывания компонентов собственной пластинки определило постоянную экспрессию рецепторов к QL-фрукозы со стороны фрибробластов и усиление до умеренной коллагеновых волокон. В собственной пластинке определены морфологические признаки гипергидратации. Экспрессия рецепторов на клетках зернистого, шиповатого, базального слоев и базальной мембраны осталась неизменной на уровне слабой.

На 30-е сутки наблюдения в эпителиальной пластинке железистой зоны слизистой оболочки твердого неба крыс реакция со стороны роговых чешуек осталась постоянной умеренной, базального постоянной слабой. Усиление связывания рецепторов определено в шиповидном и зернистом слоях до умеренного. Морфологически толщина эпителиальной пластинки достоверно уменьшилась по сравнению с показателем в интактной группе, что обусловлено нарушением процессов дифференциации по типу паракератоза.

Ключевые слова: слизистая оболочка, лектины, гипосаливация, экспрессия.

UDC [616. $311+616.315]: 615.24$

\section{INTENSITY TRANSFORMATION FOR THE MIXTURE COMPOSITIONS OF THE SOLID LUBRICATING BY LACTIN OF LARGE GRAIN LABA AT $1 \%$ EFFECT OF METHACRYLIC ACID}

Yeroshenko G.A., Timoshenko Yu. V.

Ukrainian Medical Stomatological Academy, Poltava, Ukraine

\section{Resume}

An increase in the average life expectancy of a person, the occurrence of pathology of solid teeth tissues, periodontal tissues, leads to progressive loss of teeth. In connection with this, there is a need for dentures. However, many patients $(30 \%)$ of the prosthesis can not use them, or use them only when eating and speaking.

In the practice of orthopaedic dentistry, as a monomer for the manufacture of removable denture structures, methyl ether is often used. Some authors mention "prosthetic stomatitis" in $25-69 \%$ of the examined patients and consider the cause of their occurrence the presence of an excess of monomer in the bases of prosthetics.

Administration of $1 \%$ ether methacrylic acid leads to the impaired differentiation of the epithelium and is manifested by the intensified keratinisation, caused by its direct irritating effect on the surface of the rat mucosa. Changes in the lamina propriety are manifested by the hyper hydration of the amorphous substance. Inhibited secretion, when the cytoplasm of glandular cells is densely filled with the secretary granules, is detected in the akin. Products of secretion in the lumens of excretory ducts have heterogeneous optical density.

The purpose of the work was to determine the transformation of the intensity of labelling components of the mucous membrane of the solid palm of the fucosospecific lectin, the common golden rainbow bark (LABA), under the action of $1 \%$ ether of methacrylic acid under experimental hypo salivation.

The intensity of marking using fucosospecific lection of the golden rain of the usual (LABA) mucous membrane of rigid palate under the conditions of $1 \%$ ether action of methacrylic acid is established. On the 14th day of observation, the intensity of binding of horny scalar receptors decreased to a moderate morphologically manifested by hyperkeratosis for a given period of observation. Investigation of the specificity of the binding of the components of the plate itself determined the constant expression of the receptors to aLfucose from the side of fibroblasts and amplification to moderate-collagen fibres. The morphological signs of hyperhydration are determined in the plate. The expression of receptors on the cells of the granular, spiked, basal and basement membranes remained constant at the level of the weak.

At the 30th day of observation in the epithelial plate of the glandular zone of the mucous membrane of the rigid palate of the rats, the reaction from the side of the horny scales remained moderate, basal - a constant weak. The amplification of binding of receptors is determined in the spiked and granular layers to moderate. Morphologically, the thickness of the epithelial plate significantly decreased in comparison with the intact group, due to violation of the processes of differentiation by the type of pareceratosis.

Key words: mucous membrane, lectins, giposalivation, expression. 